\title{
PELESTARIAN BUDAYA LOKAL KAMPUNG NAGA SESEBAGAI PEREKAT SOLIDARITAS SOSIAL MASYARAKAT
}

\author{
Encup Supriatna \\ UIN Sunan Gunung Djati Bandung, Indonesia \\ Email: encup.supriatna@uinsgd.ac.id
}

\begin{abstract}
Abstrak
Penelitian ini bertujuan untuk mengetahui pelestarian budaya lokal warisan hidup sederhana sebagai perekat solidaritas sosial masyarakat Kampung Naga. Penelitian ini menggunakan metode kualitatif dengan teknik pengumpulan data berupa observasi, wawancara, dokumentasi dan studi pustaka. Analisis data menggunakan model interaktif Miles \& Huberman. Lestarinya warisan hidup sederhana masyarakat Kampung Naga dilihat dari segi pola hidup, alat-alat yang digunakan, bangunan yang masih sama hingga sekarang serta dengan melakukannya menggunakan ciri khas kesederhanaan dan tradisional, keterlibatan masyarakat yang secara keseluruhan perannya masih aktif didukung dengan tingkat kesadaran yang tinggis serta rasa tanggung jawab bersama yang kuat. Sehingga dapat mejadi stimulus eksternal sebagai perekat solidaritas sosial masyarakat yang diaplikasikan dalam kehidupan sehari-hari dengan adanya bentuk kerjasama dalam gotong royong, saling membangtu antar sesama tentangga atau kelompok masyarakat.
\end{abstract}

Kata Kunci: Budaya lokal, Warisan Hidup Sederhana, Solidaritas Sosial.

\section{Abstract}

This study aims to determine the preservation of local culture of simple living heritage as the glue of social solidarity of the people of Kampung Naga. This study uses qualitative methods with data collection techniques in the form of observation, interviews, documentation and literature study. Analysis of the data using the interactive model of Miles \& Huberman. The sustainability of the simple living heritage of the Kampung Naga community is seen in terms of the lifestyle, the tools used, the buildings that are still the same until now and by doing so using the characteristics of simplicity and traditional, community involvement whose overall role is still active supported by a high level of awareness and strong sense of shared responsibility. So that it can be an external stimulus as an adhesive for community social solidarity that is applied in daily life by the form of cooperation in mutual cooperation, mutual help among neighbors or community groups.

Keywords: Local culture, Simple Living Heritage, Social Solidarity.

\section{A. PENDAHULUAN}

Budaya dan keragaman suku bangsa merupakan kekayaan yang paling utama yang ada di negara Indonesia. Sehingga melahirkan banyaknya kebudayaan yang bervariasi. Tentu dalam pola hidup dan pola kebiasaan yang berbeda akan memperngaruhi gaya kebudayaan yang berbeda-beda dan atau beragam. Bukan hanya manusia yang mempunyai akal untuk membiasakan suatu kebiasaan dalam memenuhi kebutuhan hidupnya, akan tetapi kesepekatan dari berbagai manusia juga menentukan. Makhluk yang paling berbeda dan mempunyai akal tidak lain hanyalah manusia yang memiliki kelebihan yaitu pikiran dan perasaan. dari kelebihan itu akan menciptakan suatu karya yang akan menguntungkan dirinya dan memenuhi semua hasratnya. 
E. B. Taylor mengemukakan bahwa yang mejadikan pengetahuan, kepercayaan, adat, hukum, moral, adat istiadat dan lain sebagainya yang merupakan suatu kebiasaan yang dilakukan oleh manusia sebagai salah satu bagian dari masyarakatnya yang disebut dengan kebudayaan itu sendiri. Menurut Selo Soemardjan \& Soelaiman Soemardi mengetahui bahwa kebudayaan adalah rasa yang merupakan hasil-hasil karya pikiran yang diiringi dengan jiwa serta nilai-nilai sosial yang ada dan melalui rahaniah masyarakat. Pada intinya kebudayaan dapat kerucutkan bahwa penciptaannya itu adalah dari hasil dari lingkungan sosialnya manusia berupa interaksi secara tidak langsung maupun langsung yang dilakukan oleh masing-masing individu. Yang pada akhirnya dapat dijadikan sebagai unsur yang memliki suatu identitas yang dapat membedakan dengan kelompok masyarakat yang lainnya.

Setiap kelompok masyarakat kebudayaan yang mereka hasilkan berbeda dengan kebudayaan pada masyarakat lain. Hal ini disebabkan karena pola pikir serta karakteristik masyarakatnya yang berbeda. Kebudayaan yang dihasilkan oleh kelompok masyarakat tertentu (etnik, suku, bangsa, ras, dan klan) disebut sebagai budaya lokal. Sehingga dapat didefinisikan sebagai karya asli suatu kelompok masyarakat yang juga menjadi suatu ciri khas pada sebuah kelompok masyarakat lokal. Pada dasarnya budaya lokal merupakan hasil ide ataupun gagasan dari masyarakat baik itu etnis, suku, wilayah dan lain sebagainya, sehingga budaya tersebut hanya dimiliki masyarakat lokal dan menjadi identitas dari masyarakat tersebut.

Budaya lokal bukan hanya sebagai dari hasil dari perwujudan ide serta gagasan kelompok masyarakat lokal, tetapi budaya lokal pun dapat memberi peran dalam membangun solidaritas di lingkungan masyarakat. Hal ini disebabkan karena budaya lokal adalah sebuah tradisi atau adat istiadat yang terbiasa dilakukan sebagai kegiatan sehari-hari oleh individu di dalam kelompok dan terkadang secara tidak sadar budaya lokal berperan aktif dalam membangun solidaritas sosial pada setiap kelompok masyarakat.

Jawa Barat dikenal sebagai salah satu provinsi di Indonesia yang masih menjunjung tinggi nilai budaya warisan nenek moyang yang sampai saat ini terus dilestarikan. Keragaman budaya di Jawa Barat hampir tersebar di semua Kabupaten, salah satunya di wilayah Kabupaten Tasikmalaya. Kebudayaan ini dijadikan sebuah identitas yang dimiliki masyarakat itu sendiri serta tumbuh dan berkembang di lingkungan tempat mereka tinggal. Identitas dijadikan tanda pengenal, memiliki makna pada budaya yang diciptakan oleh masyarakat tersebut. Identitas menjadi suatu karakter khusus yang melekat pada setiap kebudayaan. Kebudayaan yang diangkat menjadi sebuah identitas suatu budaya tidak diciptakan begitu saja, namun memerlukan waktu yang cukup lama untuk diketahui, diakui, ditaati dan diimplementasikan dalam lingkungan hidup.

Budaya lokal merupakan suatu hal yang merarik untuk dikaji lebih mendalam. Di Kabupaten Tasikmalaya terdapat banyak kebudayaan yang memiliki daya tarik yang cukup besar. Salah satunya adalah budaya lokal hidup sederhana Kampung Naga yang terdapat di Desa Neglasari Kecamatan Salawu Kabupaten Tasikmalaya. Kampung Naga merupakan salah satu kampung yang masih melestarikan budaya warisan nenek moyang yakni kesederhanaan dalam melakukan hidup. Masih banyak menggunakan alat-alat sederhana lalu marsyarakat kampung naga ini masih memepertahankan kabiasaanya walaupun barada di tengah-tengah zaman modernisasi sehingga masyarakat kampung naga secara sepakat menolak jaringan listrik, alat-alat elektronik dan sebagainya, ini merupakan persoalan yang menarik untuk dikaji dalam suatu penelitian ada beberapa memang banyak alasan mengapa harus menolak berbagai fasilsitas modern yang ada saat ini yang mungkin salah satunya adalah untuk menjaga kerukunan dalam masyarakat budaya lokal di Kampung naga tersebut.

Dengan adanya kesadaran masyarakat terhadap warisan budaya leluhur menunjukkan kepada masyarakat secara luas bahwa pentingnya solidaritas sosial. Rasa solidaritas sendiri menekankan kepada masyarakat akan nilai-nilai kebersamaan yang bersumber pada 
kepercayaan serta norma-norma yang berlaku di masyarakat, serta didukung oleh kebudayaan dan adat istiadat yang berlaku. Hidup sederhana sebagai perwujudan budaya lokal masyarakat Kampung Naga di Desa Naglasari yang masih tetap terjaga eksistensinya hingga saat ini.

\section{B. METODE}

Penelitian ini dilakukan di Kampung Naga yang terdapat di Desa Neglasari Kecamatan Salawu Kabupaten Tasikmalaya. Penelitian ini menggunakan metode kualitatif dengan teknik pengumpulan data berupa observasi, wawancara, dokumentasi dan studi pustaka (Sugiyono, 2018). Analisis data menggunakan model interaktif Miles \& Huberman.

\section{HASIL DAN PEMBAHASAN}

Kehidupan Kampung Naga berbeda dengan kampung-kampung yang lain dari segi ekonomi, sosial, pendidikan maupun gaya hidup sederhana itu sendiri, dalam hal ini sudah menjadi suatu tatanan yang diatur sedemikian rupa agar tetap berjalan dengan seadanya sehingga dapat mempengaruhi sebuah pola hidup yang berbeda walaupun di luar Kampung Naga kehidupan terus mengikuti zaman yang modern, alasan dari pada adat kebiasaan ini menjadi cerminan bagi semua masyarakat semua karena sebetulnya kita sebagai manusia harus bisa bertahan hidup dengan alam dan juga menjaga akan keutuhan alam tersebut.

Di samping itu, dari pola kehidupan Kampung Naga sendiri dibagi menjadi tiga bagian yaitu kawasan suci, kawasan bersih dan kawasan kotor, seperti halnya dalam menata subuah bangunan, kolam dan lain sebagainya dianggap manjadi sebuah cerminan bagi masyarakat Kampung Naga bahwa letak kehidupah masyarakat itu harus tertata agar bisa disesuaikan dengan keadaan ikilm atau alam sekitarnya karena pedomannya dari leluhurnya adalah kita sebagai penerus warisan hidup dari nenek moyang dahulu sebagai manusia yang berakal harus bisa mewarsikan mata air bukan air mata. Tujuannya adalah agar nantinya generasi-generasi selanjutnya pada masyarakat Kampung Naga bisa mempertahankan kehidupan yang sederhana dengan kearifan lokalnya.

Dalam kajian Sosiologi salah satu agen sosialisasi pertama yakni keluarga, kemudian ada sarana bermain. Dengan tumbuh kembangnya seorang anak maka sebagai orangtua perlu memperhatikan karakter yang ada pada seorang anak tersebut guna dapat mendapatkan kehidupan yang lebih baik. Salah satu aplikasi dalam kehidupan sehari-harinya yakni dengan adanya kesadaran diri serta keinginan untuk menciptakan lingkungan sosial yang harmonis, rukun dan sejahtera. Oleh sebab itu cara mempertahakan adat dan kebiasaan yang ada yiatu dengan mensosialisasikan dengan cara tidak langsung sehingga tidak ada paksaan pada setiap rukun tetangga yang ada.

Peneliti mendapatkan beberapa bagian penting dari hasil penelitian lapangan. dengan adanya pola bangunan yang harus sama, gaya hidup yang identik sama, pembagian kerja yang minim, tingkat keasadaran yang tinggi, keikut sertaan kelompok keluarga yang dominan tinggi, kepercayaan yang sama, gaya hidup yang sama dan tataletak kasawasan harus teratur sehingga kesadaran sosial dan solidaritas sosial masyarakat Kampung Naga akan terlihat nyata dan tingkat ketidak sesuaian pada masyarakat relatif akan rendah serta tidak ada batasan dalam melakukan aktivitas yang poisitif.

\section{Pelestarian Budaya Lokal Warisan Hidup Sederhana}

Beragam wujud warisan budaya lokal memberi kita kesempatan untuk mempelajari kearifan lokal dalam mengatasi masalah-masalah yang dihadapi di masa lalu. Masalahnya kearifan lokal tersebut seringkali diabaikan, dianggap tidak ada relevansinya dengan masa sekarang apalagi masa depan. Dampaknya adalah banyak warisan budaya yang lapuk dimakan usia, terlantar bahkan diabaikan keberadaannya. 
Sederhananya bahwa usaha mempertahankan, memelihara dan menjaga suatu budaya dan nilai-nilai tradisional untuk tetap berkembang dalam sebuah masyarakat yaitu pengertian dari pelestarian itu sendiri. Masyarakat harus menerima dan terus menjalankan tentang pelestarian agar budaya akan selalu tumbuh dan berkembang di dalam kehidupan nyata pada masyarakat tersebut. Kata dari awet bukan berarti melestarikan akan tetapi melestarikan artinnya upaya pemeliharaan yang berkelanjutan. Maka dari itu, masyarakat dari semua lapisan harus ada rasa saling memiliki, saling memotivasi, saling berpartisipasi. Serta harus ada pemimpin, penggerak, pendukung dan pecinta.

Nilai budaya yang dimiliki oleh setiap masyarakat mempunyai manfaat atau nilai yang besar. Mepertahankan atau upaya melestarikan kebudayaan merupakan suatu usaha yang dilakukan untuk menjaga nilai yang terkandung dalam kebudayaan tersebut, contoh adat dan kebiasaan di Kampung Naga yaitu dengan adanya warisan hidup sederhana. Kebudayaan ini merupakan warisan dari leluhur sehingga kita khsusnya masyarakat Kampung Naga harus bisa meneruskan adat dan kebiasaan yaitu gaya hidup sederhaana ini. Warisan hidup sederhana ini memiliki akar budaya yang sangat mendalam sehingga ini dapat terlihat didalam suatu pola hidupnya yang sederhana dan masih menggunakan alat-alat tradisional. Dalam mempertahankan suatu buadaya tentunya sangat beragam cara yang dilakukan akan tetapi initinya kita sebagai generasi penerus akan kebudayaan itu harus bisa meneruskan dan menjaganya. Oleh karena itu mempertahankan warisan hidup sederhana berarti melestarikan kebudayaan, adat atau kebiasaan masyarakat, menjalan kehidupan sederhana di Kampung Naga merupakan menjaga juga suatu nilai yang di berikan oleh para leluhurnya.

Masyarakat Kampung Naga memliki kasadaran yang kuat dan tingggi terhadap adat dan buaday lokal yang sudah ada sejak dulu untuk dapat mempertahankan dan melestarikannya khususnya untuk keturunan yang selanjutnya. Walaupun zaman semakin modern dan teknologi juga semakin canggih, akan tetapi budaya hidup sederhana ini tetap terjaga eksistensinya agar bisa dipertahanakan walaupun zaman semakin maju dan modern, rasa saling memiliki antar tetangga, gotong royong dan rasa saling menghormati sangat tinggi. Ini merupakan bentuk partisipasi atau upaya dalam mempertahankan budaya gaya hidup sederhana atau tradisional.

Budaya ini merupakan hasil dari nenek moyang kita bersama sehingga kiat sebagai anak bangsa harus bisa mempertahankan dan melestarikan adanya kergamaan budaya atau adat yang memeliki ciri khas masing-masing, oleh karena itu ketika ditopangnya dengan rasa saling memlikid dan mencintai maka hal ini akan menimbulkan rasa untuk mempertahankan budaya tersebut. Dengan tujuan untuk tetap mengingatkan kepada seluruh masyarakat bangsa Indonesia yang sangat kayak akan beragam budaya.

Keberlangsungan kehidupan yang sederhana merupakan mengingatkan kita satu hal yang mana bisa memberikan manfaat rahaniah bagi kita selaku yang bukan pelaku dalam mejalankannya dan juga bagi semua masyarakat Kampung Naga, dalam tujuannya untuk melestarikan suatu amanat bukan hal yang tidak ijinkan oleh ajaran Islam, mengingat segala bentuk kebudayaan yang ada di masyarakat merupakan bagian dari bentuk pengamalan dalam aktivitas religius sehingga bentuk kegiatan tersebut tidak dapat disalahkan.

Maka dari itu kita harus bangga dengan budaya sendiri yaitu dengan cara menjaga, mengembangkan dan melestarikan sehingga nantinya budaya kita tidak punah dimakan zaman, karena penting sekali untuk kita bisa melestarikan budaya kita yang sudah ada sejak zaman dahulu. Walaupun sekarang serba modern dan serba canggih bukan berarti kita melupakan atau menghilangkan kebudayaan kita, akan tatapi keberadaan budaya itu akan menyesuaikan dengan zaman yang semakin maju. Kita sebagai anggota masyarakat juga dituntut untuk bisa melastarikakn dan mempertahankan setidaknya dengan cara melakukan lebih toleran akan menjalankan kehidupan tidak lupa juga mengajarkan ke generasi-generasi selanjutnya sebaagi bentuk pengamalan ilmu pengetahuan. 
Sebelum mempertahankan suatu kebudayaan maka cara untuk melestarikannya adalah dengan mengetahui terlebih dahulu bagaimana upaya yang harus dilakukan. yang terjadi di Kampung Naga adalah masyarakat yang menetap di kampung tersebut dari 100\% keturunan Sanaga hanya $1 \%$ saja yang bertinggal di tempat terebut, oleh karena itu masyarakat setempat kebanyakan memeliki kasadaran yang tinggi dalam melakukan usaha mempertahankan semua kebudayaan pada masyarakat adat terbesbut. Jadi keikut sertaan antar keluarga masyarakat Kampung Naga sangat tinggi dan dilihat dari kerukunan atau kesejahteraannya sangat baik juga baik secara tidak langsung maupun langsung, secara langsungnya adalah dilihat dari setiap keluarga mengajarkan bagaimana hidup yang sederhana atau tradisional dan mencontohkannnya dengan tidak langsung.

Peneliti juga mendapatkan informasi dari salah satu informan yaitu keadaan solidaritas masyarakat yang terjalin sangat baik, karena adanya adat, kebiasaan atau kebudayaan yang sudah lahir sejak dahulu kala. Para leluhur zaman dulu mengajarakan kehidupan yang sederhana ini sudah menjadi bagian dari tugas utama untuk mempertahankannya, oleh sebab itu dalam segala bentuk kehidupan yang sederhana baik dari segi peralatan, kebutuhan hidup seperti bentuk tempat tinggal atau perlengkapan rumah tangga dan lain sebagainya yang menyangkut semua aktivitas masyarakat Kampung Naga.

Adat atau kebiasaan warisan hidup sederhana juga dipertahankan degan berbagai kegiatan-kegiatan seperti nikahan atau munduh mantu, hajat sasih, khitanan, kagiatankegiatan yang berbau agama juga salah satu upaya yang di dalam dengan cara yang sederhana dan tidak muluk-muluk. Selain itu komunikasi dengan aparatur pemerintahan Desa juga terjalin dengan baik dan saling sepakat juga karena ada beberapa kegiatan Kampung Naga yang tidak boleh diketahui para pemerintahan yang dianggap sakral dan rahasia. Dari kesepakatan inilah masyarakat dan pemerintah Desa bisa saling mengerti khususnya masyarakat Kampung Naga bisa tekut dan fokus untuk bisa mempertahankan adat kebiasaannya tersebut.

Dalam masyarakat Kampung Naga terdapat Adat dan juga warisan Budaya dari leluhurnya, warisan budaya ini merupakan cara bagaimana gaya hidup masyarakat Kampung Naga yang disesuaikan dengan adat atau kebiasaan yang diberikan oleh nenek moyang masyarakat tersesbut, pada budaya masyarakat Kampug Naga tentu memiliki alat-alat yang menjadi suatu bentuk fisik yang nyata apa adanya pada kearifan lokal masyarakat.

Kemodernan sekarang yang menyangkut gaya hidup yang di aplikasikan oleh setiap masyarakat tentu sangat berbeda-beda tingkatan tergantung pada tingkatan status sosial ekonominya, sehingga gaya hidup ini lah yang akan mempengaruhi keberlangsungan kehidupan masayarakat. Budaya masyarakat Kampung Naga berbeda dengan masyarakat luar yang mana harus bisa mempertahankan suatu adat kesederhanaan dalam mejalankan hidup sehingga alat-alat ini menjadi suatu ciri bagi masyarakat setempat untuk mempertahankan warisan budaya yang diberikan oleh para leluhurnya.

Keberlangsungan hidup masyarakat Kampung Naga tidak lepas dari alat-alat yang seadanya dan yang telah diajarkan serta diwariskan oleh para leluhurnya, maka hal ini suatu keunikan tersendiri di bandingkan dengan masyarakat luar atau masyarakat kota yang lebih mementingkan kebersamaan dalam segala hal bentuk kehidupan sehari-hari antar keluarga dan masyarakat.

Berjalannya waktu yang kian modern dan melahirkan alat-alat yang canggih juga teknologi yang modern pula hal tersebut tidak bisa mempengaruhi perubahan yang terjadi bagi masyarakat Kampung Naga terutama alat-alat rumah tangga yang masih sederhana atau tradisional. Hal inilah yang menjadi ciri khas yang unik bagi pandangan-pandangan orang asing yang dating ke kawasan Kampung Naga, tidak menutup kemungkinan juga ini akan mempengaruhi bagaimana para masyarakat akan terus saling memiliki terhadap ciri khas 
yang unik dan berbeda dengan masyarakat umum dan lainnya serta dengan adanya warisan budaya dari para leluhurnya.

Berdasarkan unsur kebudayaan atau adat yang merupakan peberian dari nenek moyang dahulu, tentunya alat-alat ini menjadi salah satu bagian dari unsur kebudayaan tersebut. Dengan adanya alat-alat tradisional yang masih dilestarikan fungsinya, keluarga dan seluruh masyarakat Kampung Naga tidak menutup pengakuan dan sebuah ilmu yang akan merubah pola hidup yang modern sehingga alat-alat yang digunakanpun modern dan canggih, akan tetepi ini hanya sebatas pengakuan masyarakat Kampung Naga bagi masyarakat luar atau yang disebut dengan masyarakat Sanaga, atau seperti contoh masyarakat Baduy Luar dan Baduy Dalam.

Setelah peneliti melakukan observasi melihat adanya kagiatan-kegiatan kelompok keluarga maupun masyarakat Kampung Naga yang tetap meanggunakan alat-alat sederhana atau tradisional seperti melakukan shalat magrib, isya dan subuh berjamaah menggunakan obor, kagiatan masak memasak menggunakan kompor minyak tanah atau masih tidak sedikit kelompok keluarga juga masih menggunakan tungku atau dalam bahasa Sunda yaitu Hawu, bukan hanya itu, antart tetangga Kampung Naga juga menggunakan atat-alat tradisional untuk keperluan membuat rumah dan digunakan untuk membuat anyaman seperti dalam bahasa Sunda yaitu Sangku, Boboko, Bilik, Nyiruan dan tempat sampahpun di setiap depan rumah yang terbuat oleh anyaman tradisional. Dengan alat-alat tradisional ini masyarakat Kampung Naga juga memanfaatkannya untuk kebutuhan ekonominya sehingga setiap rumah atau setiap keluarga membuat anyaman-anyaman yang dibuat dengan alat tradsional. Hal inilah yang menjadi titik fungsi munculnya solidaritas Kampung Naga, sebab hakikatnya masyrakat adalah makhluk yang berbudaya.

Kehidupan sederhana di Kampung Naga merupakan warisan orang tua terdahulu masyarakat Kampung Naga atau warisan para leluhurnya, adat ini mengandung nilai keterampilan menganyam bagai masyarakat kampung naga, bukan hanya itu nilai budi pekerti, kepribadian dan juga kebersamaan yang kuat. Dalam hidup sederhana di Kampung Naga tentu harus memliki semangat yang terjaga karena kehidupan sederhana ini mengajarkan untuk tetap bertahan hidup dengan seadaanya tidak berlebih lebihan dan hidup bersama alam.

Nilai yang terkadung dalam adat dan atau kehidupan yang sederhana ini merupakan suatu tatanan sistem yang sangat penting bagi aktivitas, lingkungan dan bagi semua kegiatan kehidupan yang di milikinya secara sederhana atau tradisional sehingga masyarakat bisa merasakan, terbiasa, menjaga dan melestarikan adat yang sudah di berikan dari para leluhurnya, dalam kehidupan yang sederhana ini juga terkandung rasa saling memeliki yang sangat kuat dan kebersamaan yang sangat kental yang ditunjukkan oleh masing-masing tetangga dan keluarga yang ada di Kampung Naga.

Pada alat-alat yang digunakan juga memiliki makna yang sangat berarti karena dengan terjaganya alat-alat tradisional yang menjadikan kehidupan juga juga menjadi sederhana hingga sampai saat ini masih terjaga dan digunakan, namun dengan berkembangnya pola pikir masyarakat yang dipengaruhi oleh keadaan pendidikan yang semakin lama semakin maju dan berkambang, sehingga dengan semuanya ini berjalan dengan kebiasaan yang serentak di masyarakat Kampung Naga bisa dinikmati dengan penuh hati. Dalam hal inilah masyarakat juga akan memliki kekerabatan, keterikatan yang sangat kuat antar individunya. Yang paling penting dalam kehidupan yang sederhana yaitu aspek peraudaraan karena dalam mayarakat semua bersaudara, diajarkan untuk mencintai yang akan menimbulkan rasa memiliki terhadap budaya lokal. Dalam kehidupan tidak terlepas hidup rukun bersaudara, kita harus saling tolong-menolong sesama manusia dan itu semua diajarkan dalam secara tidak langsung oleh para leluhur masyarakat Kampung Naga. 


\section{Perekat Solidaritas Sosial Masyarakat Kampung Naga}

Pada awalnya manusia mengenal lingkungan dalam keluarganya, berkembang di lingkungan sekitar di luar keluarganya, dimulai dari masyarakat lingkup terkecil, kemudian sampai pada lingkup yang lebih luas, seperti sekolah dan perkantoran. Dalam kehidupannya dengan masyarakat sekitar itulah manusia mengenal berbagai macam pengalaman, kebiasaan, tradisi ataupun kebudayaan. Dari berbagai pengalaman tersebut manusia menyadari bahwa sebagai manusia tidak mungkin hidup sendiri, tetapi membutuhkan orang lain dan harus saling tolong. Disinilah fungsi tradisi, adat ataupun kebudayaan sebagai perekat antarwarga.

Dalam suatu system masyarakat tentu mempunyai tatanan dan kebiasaan tersendiri sehingga bisa menjadi pembeda bagi masyarakat lain, begitu juga dengan masyarakat Kampung Naga yang memiliki kabiasaan dan adat yang berbeda dengan penduduk di luar Kampung Naga terutama pada seluruh masyarakat Desa Neglasari Kecamatan Salawu Kabupaten Tasikmalaya yang berbeda dengan tatanan Kampung Naga, ini sebuah ke unikan tersendiri yang membuat penliti semakin tertarik pada permasalahan terebut.

Upaya dalam mempertahankan suatu adat atau kebiasaan masyarakat yang menjadi budaya lokal merupakan sautu yang harus dilakukan dengan rencana dan cara yang akan menopang semua keadaan tatanan kehidupan yang sederhana, ada berbagai macam kegaitan yang menjadi jalan agar kerukunan natar tetangga semakin erat dan terus terjaga, dalam kehidupan bertetangga tentu masyarakat harus saling mengetahui bagaimanapun keadaan atau kondisi masyarakat maka disinilah bagaiman bentuk atau jenis solidartitas yang ada, kagiatan yang penting pada suatu masyarakat merupakan salah satu cara dalam menjaga dan melestarikan juga menjalin kekerabatan yang lebih erat.

Budaya lokal adalah suatu kagiatan yang disertai dengan kegiatan lainnya seperti halnya akad nikah, memperingati hari-hari besar Islam, hajat sasih, pembangunan rumah panggung dan lain sebagainya yang dapat melibatkan seluruh elemen masyarakat Kampung Naga, hal tersebut sudah menjadi warisan yang diberikan secara turun temurun darai para leluhurnya, walaupun masyarakat setempat sudah merasakan datangnya perubahanperubahan baru, zaman yang modern dan globalisasi yang semakin menguasai bebagai aspek kahidupan masyarakat akan tetapi dengan adanya hal tesebut tradisi yang sudah ada ini tidak akan merusak semua tatanan masyarakat adat.

Setiap tetangga masyarakat Kampung Naga memiliki solidaritas yang sangat tinggi, hal tersebut juga dibuktikan dengan terjaganya adat dan kebiasaan masyarakat yang menjadi sebuah tatanan hidup yang sederhana dan tetap terjaga juga eksistensi di dalam keadaan kahidupan yang berkembang. Dilihat dari sisi jenis solidaritas masyarakat Kampung Naga ini yaitu termasuk pada jenis solidaritas mekanis yaitu solidaritas masyarakat yang didasarkan pada kesamaan (homogentias) dalam kepercayaan, pandangan, nilai dan memiliki gaya hidup yang kurang lebih sama. Homogenitas ini juga terlihat pada pembagian kerja dalam masyarakat yang rendah yang mana hanya terspesialisasi menurut usia dan jenis kelamin. Dalam hal ini, orang yang lebih tua diharapkan menjadi pemimpin dan penasihat yang bijaksana sedangkan kaum hawa terspesialisasi dalam urusan rumah tangga seperti mengurus rumah, anak dan memasak. Pada tipe solidaritas ini masyarakat didasari oleh kesadaran kolektif yang kuat dan terdapat pada masyarakat primitif yang sederhana.

Rasa kebersamaan merupakan indikator terwujudnya solidaritas sosial di masyarakat. Ketika individu di dalam kelompok masyarakatnya tertanam rasa kebersamaan satu sama lain, maka nilai ikatan sosial diantara mereka sangat tinggi. Hal ini disebabkan karena dengan adanya rasa kebersamaan maka antara individu satu dengan yang lainnya memiliki kebersamaan dalam segala hal, sehingga ketika terdapat inidividu yang kesusahan, terdiskriminasi oleh pihak lain maka individu lainnya akan memiliki persaan yang sama, serta akan membantu individu tersebut, perasaan itulah yang mewujudkan solidaritas sosial dimasyarakat terjalin baik dan harmonis. 
Solidaritas sosial masyarakat Kampung Naga pada hakikatnya dapat dilihat dari bagaimana masyarakat itu beradaptasi. Terutama apabila di Kampung Naga tersebut masih memiliki warisan budaya leluhur dan seluruh masyarakat yang mempertahankan budaya semata-mata karena pewarisan budaya yang masih dijunjung tinggi baik dari kalangan dewasa, remaja maupun anak-anak. Solidaritas sosial sesungguhnya mengarah pada keakraban atau kekompakan dalam kelompok. Perspektif Sosiologi, keakraban hubungan antara kelompok masyarakat itu tidak hanya merupakan alat dalam rangka usaha mencapai atau mewujudkan cita-citanya, akan tetapi justru keakraban hubungan sosial tersebut sekaligus merupakan salah satu tujuan utama dari kehidupan kelompok masyarakat.

Peneliti menyaksikan bahwa keakraban atau kekompakan yang terjadi diantara kelompok masyarakat Kampung Naga, dalam kegiatan-kegiatan yang diselenggarakan Kampung Naga. Keakraban hubungan antara tetangga masyarakat sangat terlihat ketika bersatu saling mendukung satu sama lain. Keakraban hubungan sosial tersebut sekaligus merupakan salah satu tujuan utama dari kehidupan masyarakat masyarakat. Keadaan kelompok yang semakin kokoh selanjutnya akan menimbulkan kerharmonisan diantara anggotanya. Apabila telah terbangun keharmonisan antar masyarakat desa maka akan terjadi sebuah proses dimana masyarakat dapat membangun pola pikir serta merealisasikannya dengan kegiatan-kegiatan positif. Terutama dalam melestarikan budaya local salah satunya,

Pencak Silat disini merupakan salah satu media pemersatu masyarakat Kampung Naga dalam menjalankan aktifitas sehari-hari. Dalam kegiatan sehari-hari nampak terlihat masyarakat menerapkan apa yang terkadung dalam nilai dan makna filosofi ang terkandung dalam Kehidupan yang sederhana. Kebersamaan yang tumbuh mencerminkan dengan adanya kerjasama dalam hal apapun, semisal ketika saling membantu utuk membangun rumah yang bisa dimanfaatkan untuk salah satu keluarga. Kebersamaan yang terjalin dalam masyarakat sekaligus melahirkan persatuan antar anggota masyarakat.

\section{Budaya Lokal Warisan Hidup Sederhana Sebagai Perekat Solidaritas Sosial Masyarakat}

Berwal dari seorang indivsidu yang mengenal kelaurganya, lalu mulai maju ke luar keluarganya menuju lingkungannya, dari mulai masyarakat yang ruang lingkupnya kecil, dan menuju ke ruangan kalangan yang luas, seperti sekolah dan perkantoran. Dalam kehidupannya dengan masyarakat sekitar itulah manusia mengenal berbagai macam pengalaman, kebiasaan, tradisi ataupun kebudayaan. Dari berbagai pengalaman tersebut manusia menyadari bahwa sebagai manusia tidak mungkin hidup sendiri, tetapi membutuhkan orang lain dan harus saling tolong. Disinilah fungsi tradisi, adat ataupun kebudayaan sebagai perekat antar warga.

Setiap masyarakat mempunyai sistem sosial dan sistem budayanya sendiri yang membedakan dengan masyarakat lainnya. Mereka memiliki warisan budaya lokal yang masih dilaksanakan dalam kehidupan sehari-hari dan juga diwariskan kepada generasi selanjutnya. Budaya lokal Warisan hidup Sederhana dipandang oleh masyarakat masih fungsional dan sesuai dengan tuntutan lingkungan tempat tinggal masyarakat. Salah satu kearifan lokal dalam bentuk warisan budaya yang masih dipertahankan dan tetap berlangsung sampai saat sekarang ini dalam masyarakat Desa Wargaluyu Kecamatan Arjasari. Warisan hidup sederhana menjadi identitas kebangaan masyarakat Kampung Naga sebagai budaya lokal miliknya, disisi lain Warisan Hidup Sederhana sangat berperan bagi masyarakat sebagai perekat solidaritas sosial. Oleh sebab itu warisan hidup sederhana menjadi identitas jati diri masyarakat serta dicintai dan dijaga agar kelestariannya tetap bertahan. Warisan hidup sederhana adalah budaya lokal hasil dari ide, gagasan, serta konsep pemikiran sekelompok manusia yang berasar dari nilai-nilai sosial manusia itu sendiri. 
Adanya warisan hidup sederhana ini telah menjadi perekat solidaritas sosial yang tinggi dengan adannya kegiatan-kegiatan masyarakat di Kampung Naga Desa Neglasari Kecamatan Salawu Kabupaten Tasikmalaya sebagai pengalir terjaganya rasa asling memliki antar tetangga, itu sebabnya warisan hidup sederhana inilah bisa terjaga dan lestari khususnya di dalam tatanan kahidupan Kampung Naga. Solidaritas sosial masyarakat terlihat adanya kerjasama dalam kegiatan-kegiatan yang ada di Desa Wargaluyu seperti kerjabakti, membantu tetangga yang mengalami kesusahan. Dengan persatuan yang ada, masyarakat menjadi lebih kuat dan mempunyai solidaritas yang kuat yang mampu menghadapi permasalahan di masyarakat. Keharmonisan menunjukan kasih sayang terhadap sesama anggota masyarakat terkhusus di lingkungan masyarakat Kampung Naga Karena pada dasarnya setiap individu tidak bisa hidup sendiri, perlu bantuan dari orang lain untuk saling membantu, tolong-menolong dalam situasi apapun. Hidup rukun menjadi ciri khas masyarakat Kampung naga.

Warisan Hidup Sederhana merupakan budaya lokal masyarakat Kampung Naga, warisan hidup menjadi identitas dan pengikat sosial masyarakat Kampung Naga. Hal ini terbukti dengan masih lestarinya budaya lokal warisan hidup sederhana di masyarakat. Selain itu masih banyaknya masyarakat yang mengunakan alat-alat sederhana dalam menyelenggarakan acara perkawinan, khitanan. Hajat sasih, upacara adat sebelum panen serta sebelum dan keterlibatan masyarakat dalam mengembangkan budaya lokal warisan hidup sederhana, menjadi bukti bahwa warisan hidup sederhana masih tetap terjaga eksistensinya dan menjadi faktor strimulus eksternal dalam menjaga ikatan sosial masyarakat. Oleh sebab itu warisan hidup sederhana menjadi identitas jati diri masyarakat Kampung Naga serta dicintai dan dijaga agar kelestariannya tetap bertahan. Warisan hidup sederhana adalah budaya lokal hasil dari ide, gagasan, serta konsep pemikiran sekelompok manusia yang berasar dari nilai-nilai sosial manusia itu sendiri.

Warisan hidup sederhana mengandung nilai-nilai hubungan bertetangga yang rukun dan sejahtera. Nilai-nilai kerukunan dalam warisan hidup sederhana terwujud akibat adanya ikatan rasa kebersamaan satu sama lain yang menjadi ikatan sosial bagi masyarakat. Hal tersebut dapat terlihat dari arti makna hidup sederhana itu yang berarti hidup dengan seadanya yang sudah manjadi turun termurun. Ini menjelaskan mengenai kerukunan hidup bertetangga harus saling tolong menolong, bergotong royong dan melakukan hal bersamasama. Sehingga Warisan hidup sederhana memiliki makna filosofi untuk mengikat rasa kebersamaan masyarakat dengan mewujudkan sikap solidritas sosial pada individuindividunya.

Jika di relevansikan dengan teori solidaritas sosial oleh Emile Durkheim yang mempunyai konsep dasar pemikiran bahwa solidaritas sosial merupakan berdasarkan dengan adanya perasaan yang sama, kepercayaan yang sama, keadaan yang sama, keikut sertaan yang relative tingga, penbagian kerja yang rendah dan tingkat kesadaran yang tinggi ini membuat keterikatan kekerabatan yang kuat. Ikatan ini lebih mendasar dari pada hubungan kontraktual yang dibuat atas persetujuan rasional, karena hubungan-hubungan serupa itu mengandalkan sekurang-kurangnya satu tingkat atau derajat konsensus terhadap prinsipprinsip moral yang menjadi dasar kontrak itu (Johnson, 1986).

Solidaritas sosial di pandang sebagai perpaduan kepercayaan dan perasaan yang di miliki para anggota suatu masyarakat tertentu. Rangkaian kepercayaan ini membentuk suatu sistem dan memiliki "ruh" tersendiri. Potret solidaritas sosial dalam konteks masyarakat dapat muncul dalam berbagai kategori atas dasar karakteristik sifat atau unsur yang membentuk solidaritas itu sendiri, kemudian Emile Durkheim membagi solidaritas sosial kedalam 2 (dua) kategori yaitu solidaritas mekanik dan solidaritas organik. Bagi Emile Durkhem indikator yang paling jelas untuk solidaritas mekanis adalah ruang lingkup dan kerasnya hukum-hukum dalam masyarakat yang bersifat menekan (represif). Hukum-hukum 
ini mendefinisikan setiap perilaku penyimpangan sebagai sesuatu yang bertentangan dengan nilai serta mengancam kesadaran kolektif masyarakat. Sedangkan solidaritas organik menurut Emile Durkhem masyarakat yang dibentuk oleh hukum restitutif. Dimana seseorang yang melanggar harus melakukan restitusi untuk kejahatan mereka, pelanggaran dilihat sebagai serangan terhadap individu tertentu atau segmen tertentu dari masyarakat bukannya terhadap sistem moral itu sendiri. Dalam hal ini, kurangnya moral kebanyakan orang tidak melakukan reaksi exstra emosional terhadap pelanggaran hukum.

Berdasarkan hasil penelitian dapat di analisis bahwa masyarakat Kampung Naga termasuk dalam solidaritas mekanik. Solidaritas mekanik pada umumnya terdapat pada masyarakat sederhana, solidaritas mekanik terbentuk karena mereka terlibat dalam aktivitas yang sama dan memiliki tanggung jawab yang sama dan memerlukan keterlibatan secara fisik. Masyarakat yang berlandaskan solidaritas mekanik ditandai dengan adanya kesadaran kolektif yang kuat, yang menunjuk pada totalitas kepercayaan dan sentimen-sentimen bersama. Sehingga ikatan kebersamaan tersebut terbentuk karena adanya kepedulian diantara sesama. Solidaritas mekanik terdapat dalam masyarakat yang homogen terutama masyarakat yang tinggal di daerah pedesaan, karena rasa persaudaraan dan kepedulian diantara mereka biasanya lebih kuat dari pada masyarakat perkotaan. Durkheim menyimpulkan bahwa masyarakat primitif dipersatukan terutama oleh fakta nonmaterial, khususnya oleh kuatnya ikatan moralitas bersama, dan kesadaran kolektif.

Bentuk kesolidaritasan masyarakat Kampung Naga ini sudah terlihat dari adanya upaya untuk mempertahankan dan melestarikan budaya lokal Warisan hidup sederhana yang dijadikan sebagai identitas masyarakat Kampung Naga, terlebih kesolidaritasan masyarakat yang sangat kuat untuk mempertahankan budaya asli Kampung Naga. Selain itu dengan adanya warisan hidup sederhana keharmonisan masyarakat terjalin dengan baik, disisi lain secara tidak langsung, sadar atau tidak sadar bahwa warisan hidup sederhana ini menjadi salah satu faktor yang dapat merekatkan solidaritas masyarakat. Dengan adanya pemikiran yang samadan mempunyai cita-cita yang sama yaitu menjunjung tinggi nilai-nilai warisan nenek moyang yang harus terus terja.

\section{KESIMPULAN}

Pelestarian budaya lokal warisan hidup sederhana di Kampung Naga masih mempertahankan dan melestarikan dilihat dari segi pola hidup, alat-alat yang digunakan, bangunan yang masih sama hingga sekarang serta dengan melakukannya masih menggunakan ciri khas kesederhanaan dan tradisional, dalam hal perlatan rumah tangga seperti kompor menggunakan Hawu dan minyak tanah, televisi menggunakan aki, penerangan rumah menggunakan minyak tanah yang namanya damar dan perlangkapan rumah menggunakan anyaman dari bambu yang di buat oleh diri sediri

Perekat solidaritas masyarakat di Kampung Naga, di lihat dari teorinya Emile Durkheim yang menyatakan bahwa solidaritas akan muncul dan terbentuk dengan adanya kesamaan tempat tinggal, sistem kepercayaan serta keadaan yang sama serta tingkat kesadaran yang tinggi, maka solidaritas ini termasuk pada solidaritas mekanik. Sebab keterlibatan masyarakat Kampung Naga ini dalam aktivitas yang berhubungan dengan upacara-upacara adat, hajat sasih dan hari-hari besar Islam lainnya menjadi peran dan tanggung jawab bersama. Sehingga solidaritasnya tergantung pada kesamaan keyakinan adat dan kebiasaan masyarakat Kampung Naga yang manjadi perekat keterikatan antar kelompok keluarga dan masyarakat.

Pelestarian budaya lokal warisan hidup sederhana sebagai perekat soliaritas sosial yang mana dengan terlestarinya adat dan kebiasaan masyarakat Kampung Naga yang masih dipertahankan sampai saat ini, maka budaya tersebut menjadi penunjang bagi masyarakat Kampung Naga untuk terus mempunyai rasa saling memliki, rasa saling menghormati, rasa 
kebersamaan yang tinggi, rasa kekerabatan yang tinggi, tidak ada status sosial yang berbeda sehingga dengan adanya kebiasaan yang di lestarikan ini masyarakat Kampung Naga solidaritasnya sangat tinggi di lihat dari aktivitas antar tetangga yang saling membantu dan gotong royong seperti dalam kegiatan-kegiatan yang ada di Kampung Naga.

\section{DAFTAR PUSTAKA}

Abidin, Y. Z. (2014). Pengantar Sistem Sosial Budaya di Indonesia. Bandung: Pustaka Setia. Astuti, Y. S. (2016). Pelestarian Kesenian Khas Kampung Naga Desa Neglasari Kecamatan Salawu Kabupaten Tasikmalaya. Jurnal Geografi, 4(1).

Darusman, Y. (2016). Kearifan lokal dan pelestarian lingkungan (studi kasus di kampung naga, kabupaten tasikmalaya dan di kampung kuta, kabupaten ciamis). Jurnal Nasional, 1(1), 1-15.

Henslin, J. M. (2006). Sosiologi dengan Pendekatan Membumi diterjemahkan oleh Kamanto Sunarto. Jakarta: Erlangga.

Horton, P. B., \& Hunt, C. L. (1986). Sosiologi. Jakarta: Erlangga.

Jamaludin, A. N. (2015). Sosiologi Perdesaan. Bandung: Pustaka Setia.

Jamaludin, A. N. (2015). Sosiologi Perkotaan. Bandung: Pustaka Setia.

Juliardi, B. (2014). Ilmu Budaya Dasar. Bandung: Alfabeta.

Johnson, D. P. (1986). Teori Sosiologi Klasik dan Mordern. Jakarta: Gramedia.

Karwati, L. (2017). KEARIFAN LOKAL DAN PRILAKU MASYARAKAT KAMPUNG NAGA (Studi tentang Mitos Kampung Naga yang Berhubungan dengan Pelestarian Budaya). Jendela PLS, 2(1), 22-35.

Koentjaraningrat. (1970). Manusia dan Kebudayaan di Indonesia. Jakarta: Djambatan.

Koentjaraningrat. (1974). Kebudayaan Mentalitas dan Pembangunan. Jakarta: Gramedia.

Koentjaraningrat. (2015). Pengantar Ilmu Antropologi. Jakarta: Rineka Cipta.

Khaldun, I. (2000). Muqadimmah Ibnu Khaldun. Jakarta: Pusat Firdaus.

Mawardi \& Hardiyati, N. (2007). Ilmu Alamiah Dasar. Bandung: Pustaka Setia.

Mulyadi, dkk. (1983). Upacara Tradisional Sebagai Kegiatan Sosialisai Daerah Istimewah Yogyakarta. Jakarta: Dikbud.

Nawawi, H. (2003). Metode Penelitian Bidang Sosial. Yogyakarta: Gajah Mada University Press.

Ningrum, E. (2012). Dinamika Masyarakat Tradisional Kampung Naga di Kabupaten Tasikmalaya. MIMBAR: Jurnal Sosial Dan Pembangunan, 28(1), 47-54.

Nuraeni, H. G., \& Alfan, M. (2011). Studi Budaya di Indonesia. Bandung: Pustaka Setia.

Ranjabar, J. (2020). Sistem Sosial Budaya Indonesia. Bandung: Alfbeta.

Ritzer, G., \& Godman, D. J. (2004), Teori Sosiologi Modern. Jakarta: Kencana.

Saebani, B. A. (2008). Metode Penelitian. Bandung: Pustaka Setia.

Sunarto, K. (2004). Pengantar Sosiologi. Jakarta: Fakultas Ekonomi Universitas Indonesia.

Suharsaputra, U. (2014). Metodologi Penelitian: Kuantitatif, Kualitatif, dan Tindakan. Bandung: Refita Aditama.

Wildan. N. (2021). Pelestarian Budaya Lokal Warisan Hidup Sederhana Sebagai Perekat Solidaritas Sosial (Penelitian di Desa Neglasari Kecamatan Salawu Kabupaten Tasikmalaya). Skripsi FISIP UIN SGD Bandung.

Sonia, T., \& Sarwoprasodjo, S. (2020). Peran Lembaga Adat dalam Pelestarian Budaya Masyarakat Adat Kampung Naga, Desa Neglasari, Kecamatan Salawu, Tasikmalaya. Jurnal Sains Komunikasi dan Pengembangan Masyarakat [JSKPM], 4(1), 113-124.

Soemardjan, S., \& Soemardi, S. (1964). Setangkai Bungan Sosiologi. Jakarta: Yayasan Badan Penerbit Fakultas Ekonomi UI. 
Soekanto, S. (1989). Hukum Adat Indonesia. Jakarta: Raja Grafindo Persada.

Soekanto, S. (2015). Sosiologi Suatu Pengantar. Jakarta: Raja Grafindo Persada.

Sugiyono. (2008). Memahami Penelitian Kualitatif. Bandung: Alfabeta.

Sugiyono. (2018). Metode Penelitian Kuantitatif Kualitatif dan R\&D. Bandung: Alfabeta.

Widagdho, D., dkk. (1999) Ilmu Budaya Dasar. Jakarta: Bumi Aksara.

Wiradimadja, A., Rakhman, M. A., \& Pratiwi, P. (2018). Nilai-Nilai Karakter Sunda Wiwitan Kampung Naga sebagai Bahan Pembelajaran Ilmu Pengetahuan Sosial. Jurnal Pendidikan Sejarah Indonesia, 1(1), 103-116. 